\title{
Breakeven Time on New Product Launches: An Investigation of the Drivers and Impact on Firm Performance
}

Article in Journal of Product Innovation Management · August 2014

DOI: 10.1111/jpim.12194

\section{CITATIONS}

3

3 authors:

\section{Roger Calantone}

Michigan State University

240 PUBLICATIONS 14,627 CITATIONS

SEE PROFILE

\section{Clay Voorhees}

Michigan State University

35 PUBLICATIONS 854 CITATIONS

SEE PROFILE
READS

210
Praneet Randhawa

University of Baltimore

6 PUBLICATIONS 21 CITATIONS

SEE PROFILE

Some of the authors of this publication are also working on these related projects: 


\title{
Breakeven Time on New Product Launches: An Investigation of the Drivers and Impact on Firm Performance
}

\author{
$\underline{\text { Roger J. Calantone, Praneet Randhawa, and Clay M. Voorhees }}$
}

The ability to break even faster on new product projects is becoming increasingly critical for firms in fast-moving industries where continually reinvesting in research and development efforts matters greatly for survival. However, most research to date has focused on studying the impact of two primary innovation outcomes: sales and profits. The exclusive emphasis on sales and profit may be warranted for certain types of goods such as durable goods, but when examining the effects of new products in fast-moving consumer goods or in the entrepreneurial sphere, where cash to cash matters greatly for survival, it is critical for both researchers and practitioners to not only consider the profits and sales generated by the new product but also the time to breakeven. This paper develops a theoretical framework using the competency-based literature to examine the effects of innovation drivers (customer idea source, speed to market, product quality, and product newness) on breakeven time (BET) and project profits, and their subsequent impact on firm performance. A three-stage least square estimation method was employed using longitudinal data on 945 new product development projects and launches in the morning (breakfast) foods category. The results clearly pinpoint that for successful product innovation, managers need to consider the time taken to breakeven on new product development. Specifically, the results demonstrate that speed to market and product quality shorten BET, but customer idea source extends BET. Second, the analysis also empirically demonstrates that BET is an equally effective predictor of firm performance as project profits in the short run, but significantly a stronger predictor of firm performance in the long run $(\mathrm{t}+$ four years), suggesting that BET should be regarded as a superior leading indicator of firm performance versus product profitability for fast-moving consumer goods segment. This is an important finding that suggests firms that recoup their cash investments more quickly experience greater short-term and significantly more long-term success.

\section{Introduction}

I nnovation is a proven, successful tool to help firms sustain their competitive advantage (Damanpour, 1991; Dierickx and Cool, 1989; Harmancioglu, Droge, and Calantone, 2009; McNally, Akdeniz, and Calantone, 2011). Yet it is hard for firms to sustain innovation. Most research to date has focused on two principal outcomes of innovation: new product sales and profits (Atuahene-Gima, 1996, 2005; Cooper and Kleinschmidt, 1995; Dröge, Calantone, and Harmancioglu, 2008; Gatignon and Xuereb, 1997; Griffin and Page, 1996; Harmancioglu et al., 2009; Montoya-Weiss and Calantone, 1994). The exclusive emphasis on sales and profit may be warranted for certain types of goods such as durable goods, but when examining the effects of new products in fast-moving consumer goods or in the entrepreneurial sphere, where cash to cash matters greatly for survival, it is critical for both researchers and practitio-

Address correspondence to: Roger J. Calantone, Eli Broad College of Business, Michigan State University, East Lansing, Michigan 48824. E-mail: rogercal@msu.edu. Tel: 517-432-6400. ners to not only consider the profits and sales generated by the new product, but also the time to breakeven. Breakeven time (hereafter BET) refers to the point where the cumulative project returns equal the cumulative project investment. BET is critical for firms that are replenishing their product portfolio on a faster pace because: (1) BET acts as an indicator of innovation success, which assists the firms in making right innovation decisions in the future; (2) firms' need for cash is high, and the faster the firm is able to breakeven on their previous projects, the more revenue they have for their new innovation projects and the more competitive they stay in the marketplace; and (3) for the young firm, quick payback to angel and venture capitalists generates public awareness of success and improves future borrowing/ investment terms. Despite this potential impact, the role of BET in its ability to help firms introduce new products and improve firm performance has not been fully investigated in the literature.

Consumer preferences over time have become increasingly heterogeneous (Franke, Keinz, and Steger, 2009), and their expectations have also evolved over time. Nowadays consumers expect firms to meet their needs 
and wants in the shortest possible time, and for the firms to be able to cater to those expectations and preferences, they need to introduce products on a rapid basis. As argued above, introducing products on a rapid basis requires higher cash flow. Additionally, a recent metaanalysis by Rubera and Kirca (2012) found that innovation outputs (e.g., number of new products) have a positive effect on performance. However, they also argue that this effect has been a topic of debate among researchers (e.g., Tellis, Prabhu, and Chandy, 2009). Most research to date has focused on the inputs of innovation (e.g., the research and development [R\&D] investment and new product teams), whereas the complex aspect of converting inputs into outputs is largely absent in the literature (Hauser, Tellis, and Griffin, 2007; Tellis et al., 2009). Innovation outputs make products visible to the

\section{BIOGRAPHICAL SKETCHES}

Dr. Roger J. Calantone is the Eli Broad Chaired University Professor of business at the Eli Broad Graduate School of Management at Michigan State University. He has been recognized as an MSU University Distinguished Faculty. Dr. Calantone has authored journal and proceedings articles, five books, and several book chapters. Publications appear in journals such as: Marketing Science, Management Science, IEEE Transactions on Engineering Management, Journal of Marketing, Journal of Marketing Research, R\&D Management, JPIM, Academy of Management Journal, Strategic Management Journal, and Journal of the Academy of Marketing Science. His publications and research are mostly in product design, innovation processes, decision support tools for new product development, and organization process metrics. He has received numerous research grants and awards, and in 2013 his H-Index was 59. $\mathrm{He}$ is currently co-Principal Investigator of a National Science Foundation-sponsored project studying multiteam systems at the Facility for Rare Isotope Beams. He has done dozens of feasibility analyses for new product development, State Park deployment and expansion, and auto plant siting, as well as for various public and private enterprises.

Dr. Praneet Randhawa is an assistant professor of marketing at the Merrick School of Business at University of Baltimore. Her research centers on understanding managerial issues in services marketing, customer experience management, innovation, and new product development. Praneet's research has been published or is forthcoming in Journal of Product Innovation Management and Cornell Hospitality Quarterly.

Dr. Clay M. Voorhees is an associate professor of marketing at the Eli Broad College of Business at Michigan State University. He holds a Ph.D. in business administration from Florida State University. His research focuses on customer experience management, customer loyalty, and new product development and innovation. Clay's research has been published in Journal of Marketing, Journal of the Academy of Marketing Science, Journal of Retailing, JPIM, Journal of Service Research, Strategic Management Journal, and Journal of Services Marketing. His research has been funded by the National Science Foundation, the United States Air Force Research Laboratories' Human Effectiveness Directorate, and the Marketing Science Institute. He teaches undergraduate and graduate courses on marketing strategy and product development. consumers, but in order to make products visible to customers, firms need cash flow. Cash flow allows a firm to not only fund $R \& D$, but also provides readily available funds to support the product launch, which in many consumer categories significantly dwarfs R\&D cost wise.

This research study using the competence-based framework provides two focal contributions to the marketing literature. First, the antecedents to BET on new product development efforts were identified. In doing so, the analysis empirically demonstrates that speed to market and product quality shorten the BET, but customer idea source extends the BET. Second, the analysis also empirically demonstrates that BET is an equally effective predictor of firm performance as project profits in the short run, but significantly a stronger predictor of firm performance in the long run $(t+$ four years), suggesting that BET should be regarded as a superior leading indicator of firm performance versus product profitability for fast moving consumer goods segment.

A three-stage least squares estimation method was employed using longitudinal data to study this important gap in the literature. In the following sections, first the conceptual background is discussed, followed by development of the hypotheses examining the impact of drivers of new product performance (idea source, speed to market, product quality, and product newness) on time to breakeven and project profits, and last examination of how time to breakeven and project profits impact firm performance.

\section{Conceptual Background}

Successful innovation requires a unique combination of capabilities; this unique combination of capabilities helps in developing a product/service that either develops new needs or fulfills the existing needs of the customers better than the competition (Peteraf, 1993). Capabilities of a firm play a critical role in the process of creating new products because it is these capabilities that help not only in identifying the needs and wants of the customers, but also in identifying the right mix of firm resources that can cater to those needs of the customers (Day, 1994). Like other articles, this paper also uses the terms capabilities and competencies interchangeable (Day, 1994; Grant, 1996a).

The underlying idea of firm capabilities is embedded in the theory of competitive rationality, competencybased perspective, and the resource-based view (RBV) of the firm (e.g., Grant, 1991, 1996b; Hult, 2011; Teece, Pisano, and Shuen, 1997). These theories explain that firm capabilities such as shorter time to breakeven help 
create competitive advantages for the firms in the marketplace. These theories, however, are rooted in different underlying principles. The competency-based perspective and the competitive rationality theory are both rooted in a disequilibrium-seeking process, a marketplace of less than perfect competition. RBV on the other hand is rooted in an equilibrium-seeking process, a marketplace of perfect competition (Hult, 2011). Although they have differences, their main underlying focus is on the notion of what and how a firm could do better than their competitors by developing, accessing, and/or leveraging its unique resources.

According to RBV, firms sustain their competitive position through their assets and capabilities (Amit and Schoemaker, 1993; Barney, 1991; Barney, Wright, and Ketchen, 2001; Day, 1994). Assets are the resources that the firms have accumulated over time in the form of investments in the scale and scope of economies, efficiency of facilities and operations, band equity, etc. Capabilities on the other hand are intangible and transformed resources such as bundles of skills, knowledge, and learning that act as glue holding assets together in a way that helps the firms to continuously flex to gain a competitive edge in the marketplace (Day, 1994). Assets are the tangible resources that can be imitated, acquired, and traded for money or other goods. Capabilities, however, are the intangible and often contextually unique resources that enable firms to carry out their daily activities, and these capabilities are embedded in the firm's daily routines and operations in a manner that they become difficult to duplicate and/or trade (Dierickx and Cool, 1989). Empirical studies using the framework of RBV have found that firms within a large and a small industry differ in terms of their performance (Cool and Schendel, 1988; Hansen and Wernerfelt, 1989). These differences in firm performance signify that firms have different resources and capabilities, and these differences can have a significant impact on firm performance (Hitt, Bierman, Shimizu, and Kochhar, 2001; Mahoney and Pandian, 1992).

The competence-based theory mainly focuses on what a firm can do better than its competitors (Hult, 2011). The competence perspective not only focuses on efficient processes, but also focuses on what process is most important; in other words, it helps in setting priorities. According to Dosi and Teece (1998, p. 284), “. . . a firm's distinctive competence needs to be understood as a reflection of distinctive organizational capabilities to coordinate and to learn. By 'organizational capabilities' we mean the capabilities of an enterprise to organize, manage, coordinate, or govern sets of activities . . . a distinctive competence is a differentiated set of skills, complementary assets, and organization routines which together allow a firm to coordinate a particular set of activities in a way that provides the basis for competitive advantage in a particular market or markets." This view clearly delineates that firms learn overtime and with this learning they are able to better use their resources to compete in the marketplace.

The competitive rationality theory argues that in a high-competition market environment, product- and process-based advantages are rapidly imitated by the competition. Firms that are able to sustain their competitive advantage in a hypercompetitive market are those that learn quickly in a dynamic and growing marketplace, and are making continuous improvement to their products (Dickson, 1992, p. 69; Teece, 2009; Teece et al., 1997). Dickson argues, “. . . variation in the response rate of buyers and sellers to changes in supply and demand creates opportunities that can be imperfectly exploited by the motivated, alert, and hustling decision maker." Alertness requires that the firm is able to assess the change in the market in the most critical manner in order to be able to assess the impact of changes on all facets of market decision-making. Firms that accurately assess the needs and wants of their customer, and have the ability to innovate fast will be more competitive in the marketplace than their competitors. In an aggressive market environment, where firms are required to continuously improve products and at the same time keep costs under control (Dickson, 1992), it is logical for firms to emphasize their payback time to better position themselves compared to competitors.

In summary, this review suggests that firm capabilities in the form of developing quality products, products that are new to the market, and/or products that are launched faster from the ideation phase play a critical role in developing new products that lead to higher firm performance. In addition, this review also suggests that marketing capabilities are among the most important capabilities the firm must possess in a hypercompetitive market. In the subsequent section, hypotheses are developed based on the concept of firm capabilities (Figure 1).

\section{Hypotheses Development}

\section{Source of Idea}

Product ideas are composition of the needs of the customers and solutions to those needs (Goldenberg, Lehmann, and Mazursky, 2001). This is why a substantial portion of new product innovation is either initiated by the needs and expectations of the customers (Biemans, 


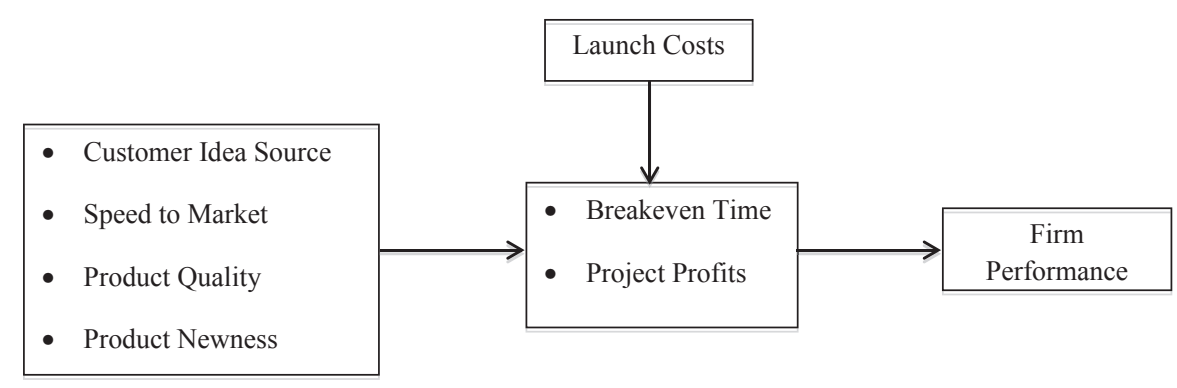

Figure 1. Research Model

1991; Utterback, Allen, Holloman, and Sirbu, 1976) or is developed by the customers themselves (Luthje, 2004; Voss, 1985). The involvement of customers in new product development cultivates products that are distinctive and of good quality (Luthje, 2004), which in turn positively impacts the performance of the product in the marketplace ( $\mathrm{Li}$ and Calantone, 1998). Firms that profitably innovate have better capabilities of implementing newer and better ideas than their competitors (Björk and Magnusson, 2009). Customers are actively involved in $10-40 \%$ of product initiatives (Luthje and Herstatt, 2004), which shows that user involvement in new product development is significantly high and a promising business strategy for firms who are aggressively involved in producing new products such as in the consumer packaged goods industry.

Generating new product ideas requires the collaboration of all in the firm (Björk and Magnusson, 2009); however, the marketing division plays a vital role in this process as they are the ones in close contact with consumers and understand their needs better. This proximity to the customers allows the marketing division to be a leader in generating customer value by distinct value proposition (Day, 2011). Additionally, marketing capabilities act as complementary rather than supplementary resources in the success of new product development by allowing for reconfiguration of competencies, reducing the resources deficiency, and creating new application of resources (Song, Droge, Hanvanich, and Calantone, 2005). Therefore, in order for a firm to innovate continuously, it needs a continuous flow of ideas and cash to develop those products. Firms with marketing capabilities will help identify the right customers who will provide the needful insights in not only developing profitable products, but also in reducing the BET to generate more cash flow to fund subsequent product development projects. Hence, the following hypotheses:
Hla: Customer-sourced ideas result in shorter BETs (i.e., ideas sourced from customers break even sooner than ideas sourced elsewhere).

H1b: Customer-sourced ideas result in higher project profits (i.e., ideas sourced from customers are more profitable than ideas sourced elsewhere).

\section{Speed to Market}

Speed to market refers to the time elapsed between the initial advancement of the idea and the final launch of the product in the marketplace (Chen, Reilly, and Lynn, 2005; Fang, 2008; Griffin, 1997). New product development speed is a critical factor for helping firms to sustain competitive advantage because in the current market environment, product obsolescence is quick, which requires the firms to launch their products in the market in a timely manner. Introducing products faster in the marketplace not only helps in generating profits (Kessler and Bierly, 2002; McNally et al., 2011; Smith and Reinersten, 1992; Vesey, 1991), but also helps in differentiating the firm from its competitors (Chen, Reilly, and Lynn, 2012). According to Kessler and Bierly (2002), faster product introductions lead to various outcomes: (1) greater learning, effective use of resources, higher level of commitment and coordination among team members, and better development of competencies; (2) better forecasting of the market needs and trends; and (3) introducing cuttingedge products in the market before the competitors. However, in order for firm to introduce products faster, it not only requires greater capabilities, but it also requires greater cash flow in order to sustain the proliferation of products in the marketplace. To date, the researchers have mostly focused on studying the impact of speed on development cost.

Despite this focus, there is no agreed upon relationship between innovation speed and development cost (Griffin, 2002; Kessler and Chakrabarti, 1999). Some studies pos- 
tulate a negative relationship between innovation speed and development cost (Emmanuelides, 1993; Kessler and Bierly, 2002; Smith and Reinersten, 1992), while others argue it is positive (Meyer, 1993; Rosenau, 1988), and yet another group of researchers claim it to be curvilinear (Gupta, Brockhoff, and Weisenfeld, 1992; Murmann, 1994). Much more can be revealed by observing the impact of speed on time taken to breakeven rather than studying its impact on development cost, the metric subtlety switches from reactive to proactive. As stated earlier, based on the literature, that speed is associated with developing better capabilities as measured by faster learning, effective use of resources, and greater ability to launch cutting-edge products than competitors. Further, if innovation speed helps build firm capabilities, then it must also help in generating both product profits and relatively shorter BET on its investment, helping the firm to keep relatively higher cash flow to continue launching new products. Hence, the following hypotheses:

\section{H2a: Speed to market has a direct, negative effect on BET (i.e., speed to market shortens the time to breakeven).}

H2b: Speed to market has a direct, positive effect on project profits.

\section{Product Quality}

Product quality refers to the threshold that the firm must meet in order to satisfy customers (Cho and Pucik, 2005). Firm capabilities are critical to build a product that meets and exceeds the expectations of the customers. Introducing high-quality products to the market is a capability that aids many objectives because it reduces customer resistance to trying new offerings (Guiltinan, 1999), acts as a barrier against competition via customer loyalty (Kerin, Varadarajan, and Peterson, 1992), and helps the firm command a price premium (Phillips, Chang, and Buzzell, 1983). Additionally, empirical literature demonstrates that product quality is positively associated with firm performance (Anderson, Fornell, and Lehmann, 1994; Cho and Pucik, 2005). One stream of literature examined the impact of product quality on return on investment (ROI), and the results showed that higher product quality is positively associated with higher ROI (Buzzell and Gale, 1987; Cho and Pucik, 2005; Jacobson and Aaker, 1987). If product quality has a strong impact on ROI, then it is logical that product quality will impact BET so that product quality reduces BET while generating greater profits. Therefore:
H3a: Product quality has a direct, negative on BET (i.e., product quality reduces the time to breakeven).

H3b: Product quality has a direct, positive effect on project profits.

\section{Product Newness}

According to Garcia and Calantone (2002), product newness can be observed in two types: really new products and incremental innovations. They argue that radical innovations are extremely rare in the marketplace. Really new products are the products that represent new technologies in the marketplace that require consumer learning and induce behavior change (Urban, Weinberg, and Hauser, 1996). These products are generally unreliable and costly to launch in the marketplace, and may take longer to be accepted by the customers (Kim and Min, 2012). Products such as Internet Service Providers, Bluetooth, and mobile phones were referred to as really new products when they were first introduced. Incremental products on the other hand refer to the products that are refined, enhanced, or adapted to satisfy the wellestablished needs of the customers (Kim and Min, 2012). These products involve lower uncertainty and costs compared with the really new products. Examples of incremental products are second generation MP3 players, different flavored cereals, and liquid detergents. Because the incremental products are targeted to meet existing needs of the customers, the market demand is steady and predictable (Urban et al., 1996). Many scholars argue that firms who understand their customers really well are able to develop products that serve the needs of the customer better than their competitors (Cooper and Kleinschmidt, 1987; Lukas and Ferrell, 2000). Therefore, firms with better capabilities than their competitors will understand both overt as well as latent customer needs better (Slater and Narver, 1998). Hence, they identify the need for a new product in the marketplace earlier than competitors, thus leading to shorter BET and higher profits for the new product. Consequently, the following hypotheses:

H4a: Product newness has a direct, negative effect on BETs (i.e., product newness reduces the time to breakeven).

H4b: Product newness has a direct, positive effect on project profits.

\section{Firm Performance}

Project profits (Cooper, 1993; Sivadas and Dwyer, 2000) and shorter BET (Carmichael, Daetz, Graves, and 
Wilson, 1991) are considered as elements of product success. Shorter BET is associated with quick recovery of the investment (Jayaram and Narasimhan, 2007) and is considered as a universally accepted and effective measure for measuring market performance (Ali, Krapfel, and LaBahn, 1995; Cooper and Kleinschmidt 1986). Moreover, many firms use BET to compare performance of multiple projects and based on those comparisons make future development decisions (House and Price, 1991). Nevertheless, the link between BET and firm performance has not been sufficiently tested in the literature. The impact of both BET and project profits is tested on firm performance. Hence, the following hypotheses:

H5a: BET has a negative, direct effect on firm performance (i.e., reducing BETs results in better firm performance).

H5b: Project profits have a positive, direct effect on firm performance.

\section{Method and Results}

\section{Data}

Hypotheses were tested using data on new product development projects and launches in the morning foods category. This category appears ideal as they are a classic example of fast-moving consumer goods that are often associated with relatively lower development costs but high launch costs related to merchandising and advertising expenses. More specifically, the data were collected on 945 new product development projects developed in 2002 and 2003, and launched in 2003 or 2004. The new product development metrics (idea source, speed to market, product newness, BET, and project profits) were developed based on a review of publically available corporate records for each firm, as well as records available from public databases such as MINTEL and subsequent coding of the antecedents by a panel of experts. Moreover, product quality was operationalized using review data from the market segment. Finally, firm performance was assessed based on book value/share source data from Wharton Research Data Services' book value/share source. The measures for idea source, speed to market, product newness, and BET were identified by public records, corporate announcements, press releases, 10Ks, 10Qs, and various other secondary sources used raw or with expert valuations. Detailed information about the constructs and their measurement is provided in Table 1.

\section{Analysis}

Tables 2 and 3 present descriptive statistics for the variables included in the research model. Because all variables were measured with single items and the conceptual model consisted of a system of equations, the research was estimated using three-stage least squares. This approach minimizes error biases in multiple equations simultaneously and is more robust to instrumentation and endogeneity problems. Within this model, all hypothesized effects were estimated as well as controlling for the effects of launch costs on BET and project profits.

\section{Results}

Overall, the research model provided a system weighted $R^{2}$ of .70 , suggesting that the model provides strong explanation of the endogenous variables. The results of the specific hypothesis testing are discussed next. Customer-sourced ideas had differential effects on BET and profitability. More specifically, H1a $(\beta=3.82$, $p<.001)$ is not supported as ideas sourced from customers are associated with longer BETs, suggesting that too much customer involvement may be too costly and not provide cash flow returns to offset these investments. Alternatively, customer-sourced ideas had a strong and significant impact on profitability of the new product development project supporting $\mathrm{H} 1 \mathrm{~b} \quad(\beta=26.82$, $p<.001)$. These results introduce an interesting contradiction between drivers of BET and profitability that are discussed in more depth in the implications section. One explanation for the negative relationship between customer-sourced ideas and BET could be that close customer involvement in the development process can result in more modification as the product advances toward launch, which results in increased retooling costs and delays in getting the product to market, which can inhibit the BET.

Speed to market emerged as a driver of both BET $(\beta=-2.48, p<.001)$ and profitability $(\beta=.70, p<.001)$, providing support for both $\mathrm{H} 2 \mathrm{a}$ and $\mathrm{H} 2 \mathrm{~b}$. Similarly the effects proposed in $\mathrm{H} 3 \mathrm{a}$ and $\mathrm{H} 3 \mathrm{~b}$ associated with the effects of product quality on BET $(\beta=-.38, p<.001)$ and profitability $(\beta=.54, p<.001)$ were also significant in their hypothesized directions. Finally, the effects of product newness on both BET $(\beta=.81, p>.05)$ and profitability $(\beta=-.11, p>.05)$ were not significant, failing to support $\mathrm{H} 4 \mathrm{a}$ and $\mathrm{H} 4 \mathrm{~b}$.

Finally, time to breakeven and project profitability both had significant effects on overall firm performance 
Table 1. Measurement

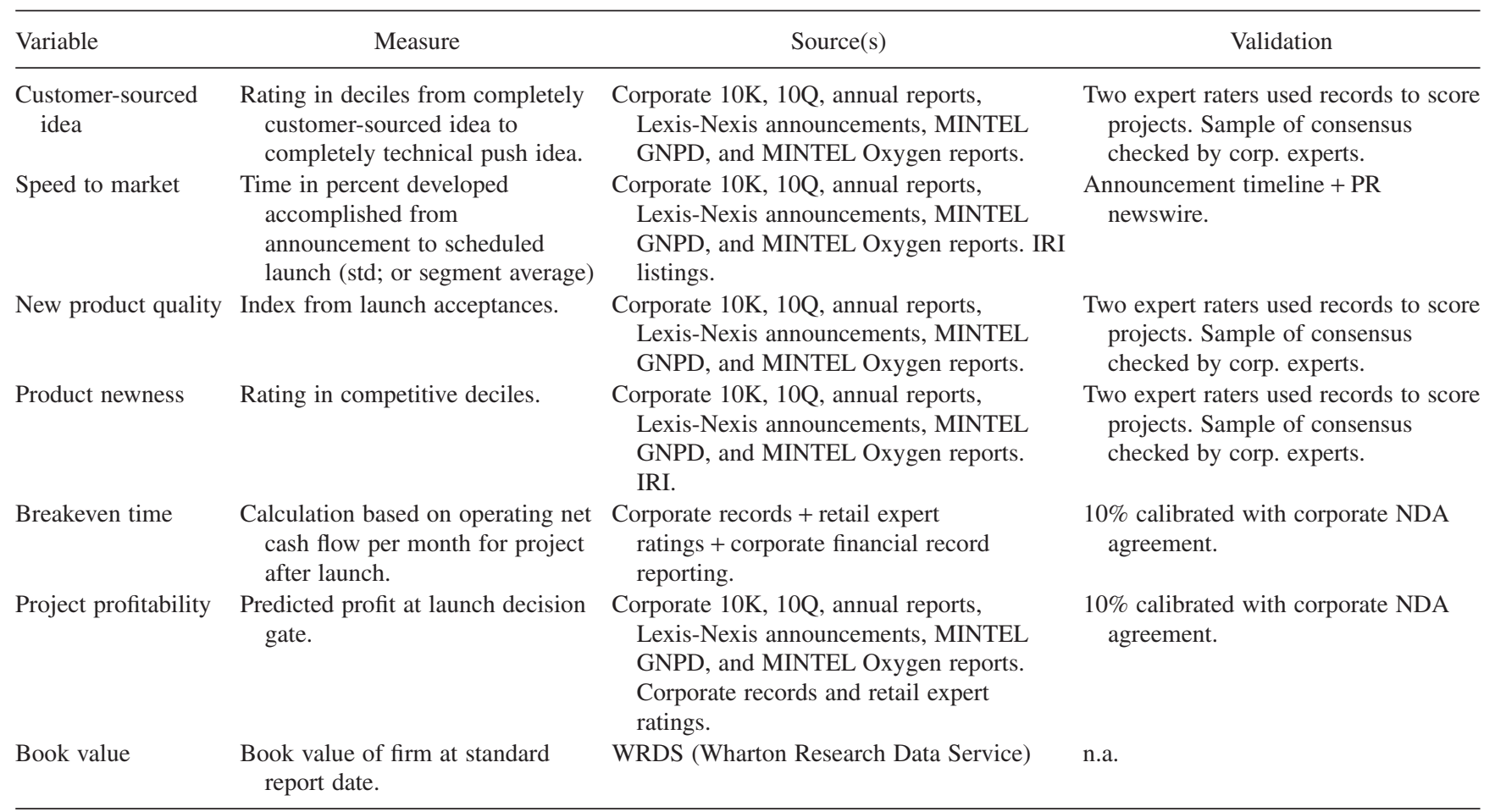

Note: Raters used most common source first. Then next most common source, and so on until all sources were evaluated then raters revised all ratings on a case, then they were tested for rank-level interrater reliability, which resulted in a score of $R R=.94$; afterwards, they conferenced and resolved inconsistencies. Finally, the composite ratings were sampled and evaluated for consistency using corporate reps under an NDA.

NDA, nondisclosure agreement; PR, press release; RR, rank-level interrater reliability.

Table 2. Descriptive Statistics

\begin{tabular}{lccc}
\hline Construct & Mean & Standard Deviation & $n$ \\
\hline Customer-sourced idea & 1.53 & .500 & 945 \\
Speed to market & 17.36 & 8.98 & 945 \\
New product quality & 59.21 & 14.72 & 945 \\
Product newness & 15.88 & 5.48 & 945 \\
Breakeven time & 82.52 & 27.2 & 945 \\
Project profitability & 34.53 & 25.27 & 945 \\
Book value per share-2004 & 10.62 & 4.13 & 945 \\
Book value per share-2006 & 11.74 & 4.74 & 945 \\
Book value per share-2008 & 17.04 & 15.17 & 945 \\
\hline
\end{tabular}

(supporting H5a and H5b), further confirming the critical role of innovation and new product development as drivers of overall performance of a firm. Interestingly, both variables had comparable effects on profitability in the short run, but in the long run BET $(\beta=-.27, p<.001)$ emerges as the dominant driver of firm performance relative to profitability $(\beta=.12, p<.001)$. These results suggest that firms that recoup their cash investments more quickly experience greater short-term and significantly more long-term success (Table 4).

Table 3. Correlations

\begin{tabular}{|c|c|c|c|c|c|c|c|c|}
\hline Constructs & (1) & (2) & (3) & (4) & (5) & (6) & (7) & (8) \\
\hline \multicolumn{9}{|l|}{ (1) Customer-sourced idea } \\
\hline (2) Speed to market & -.02 & & & & & & & \\
\hline (3) New product quality & .03 & $.48^{*}$ & & & & & & \\
\hline (4) Product newness & -.04 & $.37 *$ & $.13^{*}$ & & & & & \\
\hline (5) Breakeven time & .00 & $-.84 *$ & $-.40 *$ & $-.33^{*}$ & & & & \\
\hline (6) Project profitability & $.57 *$ & $.37 *$ & $.35 *$ & $.09 *$ & $-.36^{*}$ & & & \\
\hline (7) Book value per share-2004 & $.23^{*}$ & $.60 *$ & $.64 *$ & $.11^{*}$ & $-.52 *$ & $.59^{*}$ & & \\
\hline (8) Book value per share-2006 & $.17 *$ & $.66^{*}$ & $.70^{*}$ & $.16^{*}$ & $-.56 *$ & $.55^{*}$ & $.98 *$ & \\
\hline (9) Book value per share-2008 & -.01 & $.67 *$ & $.64 *$ & $.23^{*}$ & $-.59 *$ & $.34 *$ & $.80 *$ & $.87 *$ \\
\hline
\end{tabular}

* Correlation is significant at the .05 level (one tailed). 
Table 4. Results

\begin{tabular}{|c|c|c|c|c|c|}
\hline Constructs & BET & Project Profits & Book Value 2004 & Book Value 2006 & Book Value 2008 \\
\hline Intercept & $128.86 *$ & $-50.91 *$ & $14.34 *$ & & \\
\hline Idea source & $3.82 *$ & $26.82 *$ & & & \\
\hline Speed to market & $-2.48 *$ & $.70 *$ & & & \\
\hline Product quality & $-.38 *$ & $.54 *$ & & & \\
\hline Product newness & $.81 *$ & $-.11 *$ & & & \\
\hline BET & & & $-.08 *$ & $-.11 *$ & $-.27 *$ \\
\hline Product profits & & & $.09 *$ & $.10 *$ & $.12 *$ \\
\hline System-weighted $R^{2}$ & & & & & .70 \\
\hline
\end{tabular}

$* p<.001$.

BET, breakeven time.

\section{Discussion}

The results of the research model provide new insight into how firms can better enhance BETs on new product development projects as well as the impact that BETs can have on firm performance. In the following section, a series of explicit implications of this research for new product development managers and executives are discussed.

\section{Managerial Implications}

Balancing quality, speed, and cost. The results demonstrate the universal benefits of product quality and speed to market as they emerged as the universally positive drivers of both BET and profitability. These results provide a subtle but important contribution to new product development practice as a common mantra among new product development executives is that you can pick two of the three: (1) quality products, (2) quick development, or (3) low cost. These results suggest that in fast-moving consumer goods, developing high-quality products on an accelerated timetable may indeed cost more, but these investments are actually recouped faster under these conditions. As a result, managers may not need to struggle balancing these three seemingly antagonistic outcomes because as long as they can deliver a strong product quickly, their investment will be returned thanks to speedy infusion of product sales, thus addressing concerns associated with costs of accelerated development.

Managing customer involvement. Our results also provide interesting evidence that customer-sourced ideas ultimately result in higher profitability but take longer to break even. These contradictory results can be explained by the high costs of sourcing new product ideas from customers. Unless an organization has developed a sound infrastructure for open innovation, most customersourced ideas are identified through extensive and expensive marketing research efforts. As a result, new products developed based on customer insights must not only recoup $R \& D$ and advertising costs, but also these research costs before a profit is realized. These added costs result in longer BETs. However, in the long run, the fact that customer-sourced ideas may more closely match the needs of consumers results in greater profits. Ultimately, these results provide strong evidence for the value of customer-sourced ideas but suggest that firms must strive to develop efficient and inexpensive means of acquiring and screening these ideas in order to reduce the overall BET associated with these products.

Building better new product scorecards. Most consumer-packaged goods firms follow some variation of a Stage-Gate ${ }^{\circledR}$ process when developing new products. A critical step in these processes is the development and management of product scorecards that are reviewed at each gate review. A common challenge in developing these scorecards is the identification and weighting of success metrics that are intended to be leading indicators of product and firm performance. The results of this research provide some preliminary insight for managers in this industry. More specifically, it appears that product quality and development time are critical leading indicators for both time to breakeven and overall profitability; thus, they certainly should be accounted for at all phases of the development process, and their weight should also be increased. Moreover, given the dominant effect of time to breakeven on firm performance, firms should consider making this metric its dominant indicator for the financial performance of the new product, where profitability is relegated to a secondary, complementary role. 
Winning the battle with finance. One of the biggest struggles for brand and new product managers in the development cycle is capturing added funds needed to develop quality products and accelerate the development timeline. In most firms, the finance department that excels at tracking costs at the expense of predicting future cash flows controls the release of funds, which results in "safe" investments in established products on a routine schedule. Our results reveal that these purse strings may need to be loosened for products with high consumer appeal or quality potential so that they can be launched quickly. Specifically, speed to market proved to be a strong driver of both cash flow and overall profitability; thus, it should be viewed as a strategic investment rather than a simple cost outlay. Future research may be needed to better calibrate this give and take among these three antagonistic drivers of product success, but our results provide some evidence that overall profitability and BET can be enhanced through focusing on quality and speed; thus, the tone of the conversation with product directors and budgetary officers needs to change as these investments are strategic and can drive firm performance.

\section{Research Implications}

The results of this research provide fresh insight into new product development processes and performance. This paper demonstrates that a firm competence framework serves as an effective vehicle for understanding not only the drivers of innovation, but also firm performance. For firms to be innovative, they continuously revive their competencies to meet the market demand, and therefore researchers can considerably benefit from using the firm capabilities framework in understanding innovation success. This study empirically demonstrates that speed to market and product quality shortens the BET, but sourcing ideas from customers extends BET. Second, the analysis also demonstrates that BET is an equally effective predictor of firm performance in the short run, but significantly a stronger predictor of firm performance in the long run ( $t+$ four years), suggesting that BET should be regarded as a superior leading indicator of firm performance versus product profitability for the fast-moving consumer goods segment.

While this study offers much-needed insight into the dynamics of new product performance, there is still more work to be done. Future research studies could be developed to investigate the impact of market timing, market dynamism, and product development cost on time to breakeven and profitability to better understand the impact of BET on firm performance, and also to better understand the appropriate balance between these dimensions. Researchers also need to focus on understanding when and to what extent a consumer should be involved in the new product development phase. Is consumer involvement in the development of really new products more beneficial than their involvement in incremental innovations? Additionally, researchers need to examine the conditions that may impact the strength of BET and profitability effects on firm performance. Specifically, are these effects stable across industries and countries, and between small and large firms? Another possible avenue for future research could be to examine the synergistic effects of the drivers of innovation on BET and product profitability to fully understand and appreciate the impact of innovation drivers on BET and product profitability.

\section{Limitations}

Like any study, this research has some limitations. First, the data used for this paper come from a single industry. While the dynamics of this fast-moving consumer packaged goods context likely mirror those of many other categories, additional research is needed to replicate these effects in other contexts. Moreover, this research simply scratches the surface when it comes to identifying the potential drivers of BET in new product development projects. Future studies could focus on better identifying a comprehensive set of antecedents to new product development BETs. Finally, each firm's individual cost structure certainly affects BET, and the logical next step is to include that more explicitly both in model specification and metrics.

\section{References}

Ali, A., R. Krapfel, Jr., and D. LaBahn. 1995. Product innovativeness and entry strategy: Impact on cycle time and time to break-even. Journal of Product Innovation Management 12 (1): 54-69.

Amit, R., and P. J. H. Schoemaker. 1993. Strategic assets and organizational rent. Strategic Management Journal 14 (1): 33-46.

Anderson, E., C. Fornell, and D. R. Lehmann. 1994. Customer satisfaction, market share, and profitability: Findings from Sweden. Journal of Marketing 58 (3): 53-66.

Atuahene-Gima, K. 1996. Market orientation and innovation. Journal of Business Research 35 (2): 93-103.

Atuahene-Gima, K. 2005. Resolving the capability-rigidity paradox in new product innovation. Journal of Marketing 64 (4): 61-83.

Barney, J. 1991. Firm resources and sustained competitive advantage. Journal of Management 17 (1): 99-120.

Barney, J., M. Wright, and D. J. Ketchen. 2001. The resource-based view of the firm: Ten years after 1991. Journal of Management 27 (6): 625-41.

Biemens, W. G. 1991. User and third party involvement in developing medical equipment innovations. Technovation 11 (3): 163-82.

Björk, J., and M. Magnusson. 2009. Where do good innovation ideas come from? Exploring the influence of network connectivity on innovation idea quality. Journal of Product Innovation Management 26 (6): 66270. 
Buzzell, R. D., and B. T. Gale. 1987. The PIMS principles: Linking strategy to performance. New York: Free Press.

Carmichael, W. P., D. Daetz, S. B. Graves, and E. Wilson. 1991. Improving the product development process. Hewlett Packard Journal 42 (3): 71-76.

Chen, J., R. R. Reilly, and G. S. Lynn. 2005. The impacts of speed-tomarket on new product success: The moderating effects of uncertainty. IEEE Transactions on Engineering Management 52 (2): 199-212.

Chen, J., R. R. Reilly, and G. S. Lynn. 2012. New product development speed: Too much of a good thing? Journal of Product Innovation Management 29 (2): 288-303.

Cho, H.-J., and V. Pucik. 2005. Relationship between innovativeness, quality, growth, profitability, and market value. Strategic Management Journal 26 (6): 555-75.

Cool, K., and D. Schendel. 1988. Performance differences among strategic group members. Strategic Management Journal 9 (3): 207-23.

Cooper, R. G. 1993. Winning at new products: Accelerating the process from idea to launch (2nd ed.). Reading, MA: Addison-Wesley.

Cooper, R. G., and E. J. Kleinschmidt. 1986. An investigation into the new product process: Steps, deficiencies, and impact. Journal of Product Innovation Management 3 (2): 71-85.

Cooper, R. G., and E. J. Kleinschmidt. 1987. New products: What separates winners from losers? Journal of Product Innovation Management 4 (3): $\underline{169-84 .}$.

Cooper, R. G., and E. J. Kleinschmidt. 1995. Benchmarking the firms critical success factors in new product development. Journal of Product Innovation Management 12 (5): 374-91.

Damanpour, F. 1991. Organizational innovation-A meta-analysis of effects of determinants and moderators. Academy of Management Journal 34: 555-90.

Day, G. S. 1994. The capabilities of market-driven organizations. Journal of Marketing 58 (4): 37-52.

Day, G. S. 2011. Closing the marketing capabilities gap. Journal of Marketing 75 (4): 183-95.

Dickson, P. R. 1992. Toward a general theory of competitive rationality. Journal of Marketing 56 (1): 69-83.

Dierickx, I., and K. Cool. 1989. Asset stock accumulation and sustainability of competitive advantage. Marketing Science 35: 1504-11.

Dosi, G., and D. J. Teece. 1998. Organizational competences and the boundaries of the firms. In Markets and organizations, ed. R. Arena and C. Longhi, 281-301. Berlin: Springer-Verlag.

Dröge, C., R. J. Calantone, and N. Harmancioglu. 2008. New product success: Is it really controllable by managers in highly turbulent environments? Journal of Product Innovation Management 25 (3): 272-86.

Emmanuelides, P. A. 1993. Towards an integrative framework of performance in product development projects. Journal of Engineering and Technology Management 10 (4): 363-92.

Fang, E. E. 2008. Customer participation and the trade-off between new product innovativeness and speed to market. Journal of Marketing 72 (4): 90-104.

Franke, N., P. Keinz, and C. Steger. 2009. Testing the value of customization: When do customers really prefer products tailored to their preferences? Journal of Marketing 73 (5): 103-21.

Garcia, R., and R. J. Calantone. 2002. A critical look at technological innovation typology and innovativeness terminology: A literature review. Journal of Product Innovation Management 19 (2): 110-32.

Gatignon, H., and J.-M. Xuereb. 1997. Strategic orientation of the firm new product performance. Journal of Marketing Research 34 (1): 77-90.

Goldenberg, J., D. R. Lehmann, and D. Mazursky. 2001. The idea itself and the circumstances of its emergence as predictors of new product success. Management Science 47 (1): 69-84.

Grant, R. M. 1991. The resource-based theory of competitive advantage: Implications for strategy formulation. California Management Review 33 (Spring): 114-35.
Grant, R. M. 1996a. Prospering in dynamically-competitive environments: Organizational capability as knowledge integration. Organization Science 7 (4): 375-87.

Grant, R. M. 1996b. Toward a knowledge-based theory of the firm. Strategic Management Journal 17: 109-22.

Griffin, A. 1997. PDMA research on new product development practices: Updating trends and benchmarking best practices. Journal of Product Innovation Management 14 (6): 429-58.

Griffin, A. 2002. Product development cycle time for business-to-business products. Industrial Marketing Management 31 (4): 291-304.

Griffin, A., and A. L. Page. 1996. PDMA success measurement project: Recommended measures for product development success and failure. Journal of Product Innovation Management 13 (6): 478-96.

Guiltinan, J. P. 1999. Launch strategy, launch tactics, and demand outcomes. Journal of Product Innovation Management 16 (6): 509-29.

Gupta, A. K., K. Brockhoff, and U. Weisenfeld. 1992. Making trade-offs in the new product development process: A German/U.S. comparison. Journal of Product Innovation Management 9 (1): 11-18.

Hansen, G. S., and B. Wernerfelt. 1989. Determinants of firm performance: The relative importance organizational factors. Strategic Management Journal 10 (5): 399-411.

Harmancioglu, N., C. Droge, and R. J. Calantone. 2009. Theoretical lenses and domain definitions in innovation research. European Journal of Marketing 43 (1-2): 229-63.

Hauser, J., G. J. Tellis, and A. Griffin. 2007. Research on innovation and new products: A review and agenda for marketing science. Marketing Science 25 (6): 687-717.

Hitt, M. A., L. Bierman, K. Shimizu, and R. Kochhar. 2001. Direct and moderating effects of human capital on strategy and performance in professional service firms: A resource-based perspective. Academy of Management Journal 44 (1): 13-28.

House, C. H., and R. L. Price. 1991. The return map: Tracking product teams. Harvard Business Review 69 (1): 92-100.

Hult, G. T. M. 2011. Toward a theory of the boundary-spanning marketing organization and insights from 31 organizational theories. Journal of Academy of Marketing Science 39 (4): 509-36.

Jacobson, R., and D. A. Aaker. 1987. The strategic role of product quality. Journal of Marketing 51 (4): 31-44.

Jayaram, J., and R. Narasimhan. 2007. The influence of new product development competitive capabilities on project performance. IEEE Transactions on Engineering Management 54 (2): 241-56.

Kerin, R. A., P. R. Varadarajan, and R. A. Peterson. 1992. First-mover advantage: A synthesis, conceptual framework and research propositions. Journal of Marketing 56 (4): 33-52.

Kessler, E. H., and P. E. Bierly, III. 2002. Is faster really better? An empirical test of the implications of innovation speed. IEEE Transactions on Engineering Management 49 (1): 2-12.

Kessler, E. H., and A. K. Chakrabarti. 1999. Speeding up the pace of new product development. Journal of Product Innovation Management 16 (3): 231-47.

Kim, N., and S. Min. 2012. Impact of industry incumbency and product newness on pioneer leadtime. Journal of Management 38 (2): 695-718.

Li, T., and R. J. Calantone. 1998. The impact of market knowledge competence on new product advantage: Conceptualization and empirical examination. Journal of Marketing 62 (4): 13-29.

Lukas, B. A., and O. C. Ferrell. 2000. The effect of market orientation on product innovation. Journal of the Academy of Marketing Science 28 (2): 239-47.

Luthje, C. 2004. Characteristics of innovating users in a consumer goods field: An empirical study of sport-related product consumers. Technovation 24 (9): 683-95.

Luthje, C., and C. Herstatt. 2004. The lead user method: An outline of empirical findings and issues for future research. $R \& D$ Management 34 (5): 553-68. 
Mahoney, J. T., and J. R. Pandian. 1992. The resource-based view within the conversation of strategic management. Strategic Management Journal 13 (5): 363-80.

McNally, R. C., M. B. Akdeniz, and R. J. Calantone. 2011. New product development processes and new product profitability: Exploring the mediating role of speed to market and product quality. Journal of Product Innovation Management 28 (1): 63-77.

Meyer, C. 1993. Fast cycle time: How to align purpose, strategy, and structure for speed. New York: Free Press.

Montoya-Weiss, M. M., and R. J. Calantone. 1994. Determinants of new product performance: A review and meta-analysis. Journal of Product Innovation Management 11 (5): 397-417.

Murmann, P. A. 1994. Expected development time reductions in German mechanical engineering industry. Journal of Product Innovation Management 11 (3): 236-52.

Peteraf, M. A. 1993. The cornerstones of competitive advantage: A resource-based view. Strategic Management Journal 14 (3): 179-91.

Phillips, L. W., D. R. Chang, and R. D. Buzzell. 1983. Product quality, cost position, and business performance: A test of some key hypotheses. Journal of Marketing 47 (2): 26-43.

Rosenau, M. D. 1988. From experience: Faster new product development. Journal of Product Innovation Management 5 (2): 150-53.

Rubera, G., and A. H. Kirca. 2012. Firm innovativeness and its performance outcomes: A meta-analytic review and theoretical integration. Journal of Marketing 76 (3): 130-47.

Sivadas, E., and F. R. Dwyer. 2000. An examination of organizational factors influencing new product success in internal and alliance-based processes. Journal of Marketing 64 (1): 31-49.
Slater, S. F., and J. C. Narver. 1998. Customer-led and market-oriented: Let's not confuse the two. Strategic Management Journal 19 (10): $1001-6$.

Smith, P. G., and D. G. Reinersten. 1991. Developing the products in half the time. New York: Van Nostrand Reinhold.

Smith, P. G., and D. G. Reinersten. 1992. Shortening the product development cycle. Research-Technology Management 35 (3): 44-49.

Song, M., C. Droge, S. Hanvanich, and R. J. Calantone. 2005. Marketing and technology resource complementarity: An analysis of their interaction effect in two environmental contexts. Strategic Management Journal 26 (3): 259-76.

Teece, D. J. 2009. Dynamic capabilities and strategic management: Organizing for innovation and growth. New York: Oxford University Press.

Teece, D. J., G. Pisano, and A. Shuen. 1997. Dynamic capabilities and strategic management. Strategic Management Journal 87 (7): 509-33.

Tellis, G. J., J. C. Prabhu, and R. K. Chandy. 2009. Radical innovation across nations: The preeminence of corporate culture. Journal of Marketing 73 (1): 3-23.

Urban, G. L., B. D. Weinberg, and J. R. Hauser. 1996. Premarket forecasting of really-new product. Journal of Marketing 60 (1): 47-60.

Utterback, J. M., T. J. Allen, J. H. Holloman, and M. A. Sirbu. 1976. The process of innovation in five industries in Europe and Japan. IEEE Transactions on Engineering Management 23 (1): 3-9.

Vesey, J. T. 1991. The new competitors: They think in terms of speed to market. Academy of Management Executive 5 (2): 23-33.

Voss, C. A. 1985. The role of users in the development of applications software. Journal of Product Innovation Management 2 (2): 113-21. 